\title{
Locating an Interior world of escape in an absurd world: An Existential Reading of Let Us Compare Mythologies and the beginning of Leonard Cohen's poetics of resistance
}

\author{
Goutam Karmakar \& Shri Krishan Rai \\ Department of Humanities and Social Sciences, National Institute of Technology, Durgapur \\ (NITD), India.
}

Received March 4, 2017; Revised on June 2, Accepted June 12, 2017; Published June 15, 2017.

\begin{abstract}
Being an intensely personal poet, Leonard Cohen, one of the most important and best known poets of Canada has tried to show the inner turmoil and existential crisis of a poetic mind caught in mechanized and violent society where dehumanization compels him to create an interior world of escape. He shows how man becomes confused, disoriented and dread because of the absurd condition of the world and also tries to precede existence before essence. His 'The Spice-Box of Earth' shows an attempt to escape this world by love and 'Flowers for Hitler' along with 'Parasites of Heaven' show his passive acceptance of existence before the violence of the outer world. Not only poetry but his novel 'Beautiful Losers' also shows his false hope of rebirth and renewed vision of life. His journey towards hope finds expression in 'The Energy of Slaves' and 'Death of a Lady's Man'. And finally his quest for peace culminates in 'Book of Mercy' and in later 'Book of Longing' as his journey from innocence to experience and in again to innocence is completed. But all these begin with his very first poetic collection 'Let Us Compare Mythologies' where he has made a comparison of Christian, Hebrew and Classical mythologies to show the isolation of an individual and his experience in a seemingly violent world and how he acts out of his freedom of choice to accept the absurd condition. Further more this volume marks the beginning of Cohen's utmost desire to flee from this world into his own creation, a world of escape which is nothing but philosophical suicide. So this paper makes an attempt to show how Cohen from the very beginning has taken stance to emphasize the very existence of the individual by accepting the absurd with resistance in order to attain a sense of innocence with his desired purified version and experience.
\end{abstract}

Keywords: Absurd, Death, Cohen, Existence, Peace.

\section{Introduction}

"Perhaps in Cohen's world the things he writes about exist, but only rarely do they touch on my personal experience. I admire the poems tremendously; they are the work of a master craftsman, who must simply be living in another time dimension than my own". -(Purdy 1965, 10)

The whole poetic oeuvre of Leonard Cohen is a journey from innocence to experience and again a back to apparent notion of innocence and this whole cycle centers round his own creation of an escape world for he has understood the necessity to ascertain one's existence before the absurdity,

(c) AesthetixMS 2016. This Open Access article is published under a Creative Commons Attribution Non-Commercial 4.0 International License (http://creativecommons.org/licenses/by-nc/4.o/), which permits non-commercial re-use, distribution, and reproduction in any medium, provided the original work is properly cited. For citation use the DOI. For commercial re-use, contact editor@rupkatha.com 
violence and brutality of the society which create a feeling of nothingness and in-authenticity or bad faith. From the very beginning he has tried to show how reason fails to deal with the depth of life and man is trembling out of anger, fear and anxiety after his encounter with nothingness and generally nausea comes for he is in clash between freedom and choice more clearly bad faith. In his 'Let Us Compare Mythologies' he shows how man is feeling like a stranger after being cut off from his transcendental, metaphysical and religious root and how his actions become absurd in this world which is full of violence and deprived of light and illusions. And he also questions regarding the base and value of the mythologies to draw a conclusion with his innocence to rationalize the violence of death and life and his wish to escape into a world created by him to avert this inward and outward violence. In order to avert this violence he has relied on love with its attendant as he like a Messiah figure has tried to control his and his beloved's destiny with a quasi-religious state of grace and this grace sometimes has enabled to establish a communication of him with God. But where love has failed to help him to escape he has accepted the absurd condition. So the debut poetic collection of Cohen is not focused on only love or self actualization of a youth but a man's quest to exist to find whether life has any value or not within the framework of surroundings in which he was born.

\section{Beginning Poems and Cohen's Existential philosophy of Death and Nothingness}

The basic characteristic features of existentialism consist of nothing or the void and consequent death. When man fails to define the very essence then he becomes ignorant of all political theories, sciences, philosophies and religions for he is in existential crisis. Cohen in this volume shows this where there nothing remains to structure the very existence of man's world before apparently violent world and nothingness remains in his life and this very nothingness comes in the form of death. 'Let Us Compare Mythologies' begins with an elegy for Cohen here shows the violent world and his inner world through the fate of Orpheus who is a poet and musician found in classical mythology. When Orpheus is cast into the Hebrews by some Maenads, he has found escape not in death or alienation or exclusion but in rebirth and regeneration in a world which was created by him through his art. Cohen in the same way tries to build a new world of beauty and escape through the poetic flavor and the concluding lines from his elegy illustrate it fully. For Cohen the inner world looks like "but in the warm salt ocean/he is descending through cliffs/of slow green water/and the hovering coloured fish/kiss his now-bruised body/and build their secret nests/in his fluttering winding-sheet." (Cohen, 1956, p.13) Phrases like 'hovering coloured fish' and 'slow green water' show the gentleness of his world which is far away from harshness and brutality. Here Cohen reminds his readers about Milton's Lycidas as his way of escaping the absurdity through death by drowning. Cohen believes that death is nothing but nonexistence of man for it can end the absurdity of human existence. After Duncan Campbell Scott it is Cohen who shows death as final nothingness in Canadian literature which is also known as drowned poet theme.

From the very beginning Cohen is haunted by existential crisis as he realizes the absurdness of modern man who is feeling alone in this techno-centric society where man is in struggle with the universe and Cohen with reality. In his 'Twilight' he describes the society as "those days were just the twilight/and soon the poems and the songs/were only associates/edged with bitterness." (Cohen, 1956, p.53) Here again Cohen shows his stoic acceptance of reality through death. He shows that like Orpheus who was unable to elevate himself through his music and poetry, modern man also unable to seek any solace by remembering his lost love and youth and only a death can alternate this condition for him as death can only bring a promise to a man 
whom "like fire-twisted shadow of dancers/alternates would array themselves/around his wicker chair/and he regretted everything." (Cohen, 1956, p. 53) For him death is not viewed as a biological process but an awareness which tell that one has reached the ultimate state of nothingness. In some other poems Cohen relates his idea of death with Heidegger who in his 'Being and Time' shows death as a prime concern to gain authenticity. Cohen tries to relate what Heidegger says regarding death:

"Only by the anticipation of death is very accidental and 'provisional' possibility driven out...Once one has grasped the finitude of one's existence; it snatches one back from the endless multiplicity of possibilities." (Heidegger, 1985, p. 435)

Death can release a man from earthly afflictions and one should not mourn over it for death brings promise of a new world and a new life. In his 'Rites' he shows how death has released his father from a life as his father is "on a blood-sopped pillow,/his heart half rotted/and his throat dry with regret." (Cohen, 1956, p.19) And at the end of the poem this death opens a new world for the son and takes the role of the father. So death is essential for replacing the old suffering one with new hope. Like an existentialist Cohen tries to assert the nature of the world through death for it creates a feeling of fear and anxiety which shocks existence and there arises the question of authenticity. His philosophy of death as an escape tool reaches to its climax in his 'Item' where a new born eagle approaches death to escape the arrow of the hunter. Here he tells, "Let the stillborn eagle demonstrate/how he avoided the arrow/with its predicament of death." (Cohen, 1956, p.24) So the paradoxical vision of death according to Cohen serves for manifold purposes.

But death can't be a way to escape if the pain of living remains unknown. Death can be horrible and inflictions if one remains unknown of the fact of dying for the life after death remains a mystery and the new born will have to face the same violence and harshness of the world. Here he takes death as a finite freedom for one's acceptance of death as the supreme reality helps one to face the absurd world it its own way. In his 'City Christ' he tries to tell that one should not fear death irrespective of knowing the consequences for the heroes in battle sacrifice their life without thinking anything and they wait patiently to meet their destiny. The Christ also has not thought about his sacrifice for his sacrifice gives a hope for the people to face the violence. Cohen says here for one such hero who "blinded and hopelessly lame/he endures the morning streetcars/and counts ages in a Peel Street room.” (Cohen, 1956, p. 25)

\section{Philosophical Suicide and Cohen's portrayal of Death on a larger scale: Crucifixion of Christ and Sacrificial death of Gods}

In his later poems Cohen shows the sacrifices and death of God as a way to face the absurd condition of the world and here he confirms with Camus where this sacrifice and death is nothing but a philosophical suicide which is a "confession that life is not worth living; it is a choice implicitly declaring that life is too much. Suicide offers the most basic way out of absurdity: the immediate termination of the self and its place in the universe." (Camus, 4) In his 'For Wilf and his house' Cohen begins to crosscheck the death of gods whether those deaths are sacrificial or not. He realizes that the violence from which he is escaping rests in the very heart of his own race as he says, "when the young Christians told me/how we pinned Jesus/like a lovely butterfly against the wood,/and I wept beside ..." (Cohen, 1956,p.14) Here he talks about the Jewish people and the crucifixion of Christ as guilt on part of the Jewish as this vision of Christ's sacrifice embodies in a form of plurisignation and haunts him. This fear sometimes makes him a disbeliever of the religion as he has discovered some major inconsistency there. But later he has 
attained a kind of wisdom where he begins to love the saint and able to even question the ways of life which decreed death for he now "mourn the crushed ant/and despise the reason of the heel." (Cohen, 1956, p.14) His maturity is more shown where he understands the absurdities of life and death and accepts the bad and good elements of Judaism and Christianity. Here the very notion of crucifixion not only denotes his faith in Christ but also makes him able to get inspiration to face the absurd.

Cohen realizes an elaborate lie as he says once, "Then let us compare mythologies/I have learned my elaborate lie/of soaring crosses and noised thorns." (Cohen, 1956, p.15) He understands the rationality of untimely death and violence and gradually understands Kierkegaard's notion of 'Leap of Faith' with the sacrificial death of gods. Death of Christ is justified for he was the son of god and he has sacrificed his life the benefit of man. So for Cohen, the elaborate lie consists of rationalized sacrifice and justified death in the name of sacrificial suicide which provides a man a kind of pseudo-solution to face the absurd. In his 'Ballad' Cohen again deals with the crucifixion of Christ. But here he questions about this sacrifice which becomes futile for he is not sure whether Christ's sacrifice will bring new life for people gives example of this but fails to derive any lesson from it. And as a result he shows the useless Christ's sacrifice, "will petals find roots/in the wounds where I bleed?/...and men from Golgotha/assure me that still/gardeners in vain/pour blood in that soil." (Ballad, 43)

\section{Clash between Hebraism and Hellenism and the notion of Bad Faith: Cohen's the Song of the Hellenist}

Cohen understands that the violence exists everywhere and for this he tries to show how the violence is shown towards his people. In his 'The song of the Hellenist', he portrays the centuries old clash between Hebraism and Hellenism from Hebrew point of view to show how the Greek alliance of the Decapolis is accepted by his people. Cohen is here to show how man out of his very religion tries everything only to get salvation and ideal perfection in life. Here he points out how the Hebrew out of pressure adopts false values and gradually rejects their own freedom by acting inauthentically with their resentment and self-deception. In order to escape the absurdities of the world they adopt Greek cultures only to increase their anguish and the nausea. By accepting the Greek culture to gain freedom they only deny the existence of freedom. Cohen here points out the habits of the Hebrew people as they deceive themselves by thinking that they don't have freedom to make a choice and whey they choice to take a culture which is easy, safe and exists they fail to recognize the multitude of other choices. And naturally they have to face the consequences for accepting false social roles and alien value systems. Cohen shows how the Hebrew find themselves stuck in between reflective and pre-reflective consciousness and their bad faith is nothing but a paradoxical free decision to accept Greek cultures only to deny to themselves the inescapable freedom.

The people of Jerusalem are highly influenced by Greek cultures and accept the opposite culture as he says:

"O cities of the Decapolis across the Jordan,/you are too great; our young men love you,/and men in high places have caused gymnasiums/to be built in Jerusalem./I tell you my people, the status are too tall./Beside them we are small and ugly,/blemishes on the pedestal." 
(The song of the Hellenist) They are so much influenced that even priests and religious preachers take Hellenic notions of physical prowess and eventually sacrifice their gods. Greek gods come into domination and even the Hebrew people fear to utter their religion and gods for they are ugly and small in comparison with Greek gods and peoples. Thus the very attempt to take other religion and culture create a feeling of fear and violence among the Hebrew people and the sacred heritage of Cohen's native people is at stake. How this transformation only befools his people and takes the very hope of freedom is shown by Cohen in a beautiful rhetorical way:

"Have you seen my landsman in the museums,/the brilliant scholars with the dirty fingernails,/standing before the marble gods,/underneath the lot?/Among straight noses, natural and carved,/I have said my clever things thought out before;/jested on the Protocols, the cause of war,/quoted 'Bleistein with a Cigar." (Cohen, 16)

Hebrew's acceptance of Greek culture only brings horror and a sense of alienation for them and they remains unable to face the absurd condition for their free choice leads them to selfdeception and the narrator in this poem describes the implication as sardonic in these lines: "...I made them laugh/when the child came in:/Come I need you for a Passover Cake.” (Cohen,17)

\section{Facing the Absurd and Anxiety with Individuality: Later Poems of Cohen and the notion of Existence Precedes Essence}

After the beginning few poems on death and philosophical suicide by sacrificial death of god and the bad faith of the Hebrews Cohen tries to assert the very existential crisis of man. But he is still facing the harshness and violence of the world and unable to remain free from the absurdity. But in the later poems he defines the concept of existence and essence. He shows the passive acceptance of man's fate to establish his individuality and existence by confronting the essence characterized by the absurd abstractness. Essence is what the individual has been and what you are or your essence is the outcome of your existence and when one makes himself able to accept his lot then he establishes his existence and individuality. Sartre in 'Basic Writings of Existentialism' shows it taking man's existence into account:

"We mean that man first of all exists, encounters himself, surges up in the world-and defines himself afterwards. If man, as the existentialist conceives him, is indefinable, and he himself will have made what he will be...Man is nothing else but what he makes of himself." (Sartre, 2004, p.345)

Like a true existentialism Cohen also believes that individuality is needed to achieve an authenticity of one's existence. Here he echoes with Kierkegaard and Sartre and gives supreme importance to subjectivity. Cohen believes that one can ignore objectivity by probing inward anxiety and absurdness and when one gains the courage to face the harshness and brutality of the world then he can be able to regain meaning and existence through a divine appreciation.

'Let Us Compare Mythologies' begins the journey of an innocent soul and naturally maturity is far away for the soul starts to experience the outside world. Cohen takes love as his subject in his 'Lovers' to show his poetics of passive acceptance of the world. The woman in this poem is a Jewish lady and the man is a soldier and they are seen trading their love when Poland and Germany face violence because of the numerous murders of the Jewish people there. Love can take place at any situation for it has the power to transcend the barriers of religion, caste, nation and race. Cohen shows in a very pitiful way the soldier's final attempt to take hold his love before the fire burns her body. Here the violence of her death is in clash with the passion of their love 
and it is shown: "And in the furnace itself/as the flames flamed higher/he tried to kiss her burning breasts/as she burned in the fire." (Cohen, 1956, p.33) Here lies the essence of the poem where the soldier is left alone wandering as he has with him the memory of his love and the burden of her death while the woman takes with her the affirmation of the soldier's love. The soldier here feels cheated and plundered and both of them perhaps passively accept their fate. Cohen relates this notion with the Jewish people who also passively accept their grievous misfortunes and death is the only outcome for them to enter in a new land of hope and peace. So through accepting the reality they not only regain individualism but also establish the very existence.

In his 'Letter' the narrator in involved in a love affair and they are fully aware of the harshness and violence associated with them but those bloody man and violent are nothing to them for they are engaging to taste their body by moving their mouth across their body. But they have full knowledge of the outside violence and they know that they will also become victims of the war:

"Do not think I do not understand/what happen/after the troops have been massacred/and the harlots put to the sword/...that when one morning my head/hangs dripping with the other generals/from your gate." (Cohen, 1956, p. 37)

Individuals are free to take any action and decision and by their own existence they encounter and surge in this absurd world and as a result they become able to define themselves. Here in 'Letter' Cohen shows how the narrator emerges victorious by accepting the fate and horror and it is shown: "...all this was anticipated/and so you will know that it meant nothing to me." (Cohen, 1956, p. 37) Cohen here thinks only about man's individuality and existence but also the anxiety. It is anxiety which enables one to inform about choices, personal responsibilities and self-awareness to lead to self-consciousness. One can realize one's freedom, limitations and identity through anxiety. Cohen shows how the absurdness and resulting anxiety helps a man to obtain knowledge and the boundary of his limitation and possibilities and here his poems illustrate Karl Jaspers' view of existence which is related to being. His verse here asserts human action "by consciously recognizing his limit, he sets himself the highest goals. He experiences absoluteness in the depths of selfhood and in the lucidity of transcendence." (Jaspers, 1986, p. 2) Cohen in his 'Jingle' shows this by portraying the submission of an animal and his brain for the society. Here his submission of own brain produces a Kafka-like feeling as he says: "So here is mine,/torn and stretched for the sun,/to be used for a drum or a tambourine,/to be scratched with poetry/by Kafka's machine." (Cohen, 1956, p. 37) Here he shows how man gains individuality when he realizes that he can't control the outside world but can accept it and thus gains opportunity to win over the situation to hold his existence. This type of acceptance and submission can be seen in his 'Story' where he shows how a woman, preoccupied with the thought of death narrates a child's death is a traffic accident and the poet here does not change her thinking but like her he also accepts the destiny for they realize that any efforts to change the fate will be futile. The poem ends with a note of accepted individualism and existence: "I take my place/among the paper fish and make-believe clocks,/naming the flowers she has drawn,/smiling while she paints my head on large clay coins,/and making a sort of courtly love to her/when she contemplates her own traffic death." (Cohen, 1956, p.63).

For Cohen absurd means nothingness and meaningless and one can't get any meaning in the world except we give it any meaning. Cohen shows how individual's attempt to achieve unattainable goals makes one's life absurd. So the absurdity lies in the choices and actions of human being and in the conflict between one's attempt to seek meaning in life and the subsequent failure to gain the inherent value. In his 'Ballad' Cohen shows how a sex-crazed 
maniac murders his beloved out of horror and anxiety and the lady here lies "naked on an old bed, knife slashes/across her breasts, legs badly cut up:/dead two days." (Cohen, 1956, p.46) But in this very poem he seems to embrace this absurd violent nature of the murderer and death by juxtaposing the horror and the satire on the murderer and the concluding lines show his acceptance of the beauty of the women which restorers the existence of women in general. Here he asserts: "We buried her in Spring-time./The sparrows in the air/wept that we should hide with earth/the face of one so far/The flowers they were roses/and such sweet fragrance gave/that all my friends were lovers/and we danced upon her grave." (Cohen, 1956, p.47) In Cohen's world man is deprived to lead a peaceful life for the world is so depressing that it promises nothing and this very thought is reflected in his 'The Sparrows' where the winter season is shown as such dark and gloomy that Cohen can't think Spring as a season of rebirth and joy but "disturbs us like the morning/...the age of lust is giving birth." (Cohen, 1956, p.20) Such is the condition of human being that he can't take the spring even they seem too tired to think and begin for they are now spiritual waste land capable of thinking nothing.

As man is now separated from nature, god and other people, he is forced to live a life of alienation and his own true self reaches at higher levels of abstraction leaving him dread, ridden and weak. He is going through life-in-death situation and his own world is perverted and destructed and Cohen while showing this agrees with what Edward Engelberg says in 'Solitude and its Ambiguities in Modern Fiction':

"Modern solitude goes far beyond anxiety and nightmare: it only annihilates motion, it retards and destroys emotion. When affect is arrested, when there is no root to society...when the ego is self-devouring, then we have reached a state of solitude beyond alienation-the state of silence." (Engelberg, 2001, p.39)

In such condition even the most beautiful sights like the sunset and its beauty becomes violent and harsh for a man and Cohen in his 'Prayer for Sunset' shows how "the sun is tangled/in black branches/raving like Absalom/between sky and water,/struggling through the dark therewith/to commit its daily suicide." (Cohen, 1956, p.41) But he sees the sunset to its fullest however "terrified by the clash of wind on grass/and the victory cry of weds and water" (Cohen, 1956,p.41) for he believes that man can make out the meaning of his essence by facing hostile challenges and gradually asserts his existence both in ethical and aesthetic way in this unknowable world.

\section{Freedom of Choice and Responsibility: Cohen's acceptance of the absurd and interior world of peace and optimism}

Cohen's view of the world is not only pessimistic for he tries to accept the absurd to create an internal world of peace and his optimistic views are also shown as he believes what Sartre says in 'Existentialism is Humanism': "In any case, we can begin by saying that existentialism, in our sense of the word, is a doctrine that does render human life possible; a doctrine, also, which affirms that every truth and every action imply both an environment and a human subjectivity." (Kaufmann, 1956, p.346) Cohen asserts that freedom is choice is very crucial for an individual for it refers one's ability to mould his circumstances according to his choices and commitments. One has to take a risk to accept what he feels necessary and this choice ultimately leads him to face the absurd. It is the choice through which one can not only deny conventional notions and values but also can replace those with own choice and will. In his 'Prayer for Messiah' he chooses to send out the raven before the dove for he believes that violence symbolized by the raven should precede 
peace which the doves present and he ends the poem with his freedom of choice which gives a vague image of approaching optimistic future: "O break from your branches a green branch of love/after the raven has died for the dove." (Cohen, 1956, p.18)

Cohen rightly says that freedom of choice to face the abstract much come with a responsibility which gives a man necessary boost and pressure to build his own world of peace by taking help of his choice along with his acceptance without resignation. In his 'Song' he chooses love as the weapon to build an interior world of beauty and peace where the lover and the poet can live safely and his thoughts will protect his beloved's beauty for it is responsibility. The poet says: "May soft birds/soft as a story to her eyes/protect her face/from my enemies." (Cohen, 1956, p. 30) He says that this new born world of love and peace can face any obstacle and violence for he is defending with his words and also urges his lover to think only about himself for "thinking of my name/turning my bronze name/over and over/with the thousand fingers/of her body/anointing her shoulders/with the remembered odour/of my skin" (Cohen, 1956,p. 30) Here the poet becomes a rebel who fights against life's formlessness and disunity to make it worth living and this very idea to gain immortality and peace are reflected when he says: "O I am the general/in her history/over the fields/driving the great horses/dressed in gold cloth/wind on my breastplate/sun in my belly." (Cohen, 1356, p.30) Here he tries to put everything in order by becoming a Messiah like figure. He begins to rule the absurd world with his state of grace and this is further heightened when John Ruddy illustrates in MacLean's Magazine:

"A state of grace is that kind of balance with which you rise to the chaos you find around you. It's not a matter of resolving the chaos, because there is something arrogant and warlike about putting the world in order." (Ruddy, 1966, p.18)

\section{Conclusion}

Cohen is very much known to the fact that his creation of an imaginary world serves an immediate purpose to face the absurdities and violence of the world. But this absurdness provides way for peace to enter and although this peace and inward safety works like a temporary substitute but build the foundation of his later volumes. So Let Us Compare Mythologies shows not only the lyrical genius of Cohen but also his preoccupation with absurd and nothingness along with his resistance or acceptance of this violence by showing not only the crucifixion of Christ and sacrificial death of gods but also the depth of love which enable him to counter alienation and hopeless. His world becomes a place of violent contrasts as there remains a clash between brutality and gentleness. His dealing with existential crisis revolves round man and here he echoes with what Thomas Flynn says regarding existentialism: "Existentialism is a personcentered philosophy. Though not anti-science, its focus is on the human individual's pursuit of identity and meaning amidst social and economic pressures of mass society for superficiality and conformism." (Flynn, 2006, p. 8) Cohen believes that peace will come and Isaiah's foretelling will be fulfilled with the coming of true Messiah. And gradually Cohen's man becomes an absurd hero by revolting consciously against the absurdity, harshness and violence of the world and his later volumes show man's struggle to gain peace and hope by recovering his existential crisis and accepting nothingness. And Let Us Compare Mythologies marks the beginning of a new era where man's refusal to hope gives foundation to live passionately in this absurd world for from the very beginning he has faith in man and here readers place him with Camus and his saying in "The Rebel': "Man has an idea of a better world than this. But better does not mean different, it means unified. This passion, which lifts the mind above the commonplace of a dispersed world, from 
which it nevertheless cannot free itself, is the passion for unity. It does not result in mediocre efforts to escape, however, but in the most obstinate demands. Religion or crime, every human endeavor in fact, finally obeys this unreasonable desire and claims to give life a form it does not have." (Camus, 1961, p.64)

\section{References:}

Bascom, William. (1965). “The Forms of Folklore: Prose Narratives”. In Journal of American Folklore, 78: 519.

Camus, Albert. (1955). The Myth of Sisyphus, and Other Essays.Trans. Justin O'Brien. New York: Knopf. ---. (1961). The Rebel. Trans. Stuart Gilbert. New York: Knopf.

Cohen, Leonard. (1956). Let Us Compare Mythologies. McGill Poetry Series,Toronto: Contact Press.

Engelberg, Edward. (2001). Solitude and its Ambiguities in Modern Fiction. New York: Palgrave.

Flynn. Thomas. (2006). Existentialism: A Very Short Introduction. New York: Oxford University Press Inc.

Frye, Northrop. (1971). The Bush Garden: Essays on the Canadian Imagination. Toronto: Anansi Press. Gnarowski, Michael. (1976). Leonard Cohen:The Artist and His Critics. Toronto: McGraw-Hill Ryerson. Guignon, Charles. (2004). The Existentialists: Critical Essays on Kierkegaard, Nietzsche, Heidegger, and Sartre. Lanham, MD: Rowman \& Littlefield.

Heidegger, Martin. (1985). Being and Time. Trans. John Macquarrie \& Edward Robinson. Oxford, U.K: Basic Blackwell.

Hodge, Joanna. (2001). Heidegger and Ethics. New York, USA: Routledge.

Jaspers, Karl. (1986). The Origin and the Goal of History. (Ed.) Edith Ehrlich, Leonard H.Ehlich. Athens: Ohio University Press.

Kaufmann, Walter. (1956). Existentialism: From Dostoevsky to Sartre. New York: Meridian Books, Inc.

Michelman, Stephen. (2008). Historical Dictionary of Existentialism. Lanham, Maryland: The Scarecrow Press, Inc.

Nadel, Ira B. (2007). Various Positions: A Life of Leonard Cohen. Austin: University of Texas Press.

Pacey, Desmond. (Autumn, 1956). “A Group of Seven”. In Queen's Quarterly, LXIII,3: 438-440

Purdy, A.W. (Winter, 1965). "Leonard Cohen: A Personal Look”. In Canadian Literature, 23:1, 8-12.

Ruddy, Jon. (October, 1966). Leonard Cohen. MacLean’s Magazine, 59:7, 16-18.

Sartre, Jean-Paul. (2004). “Existentialism”. In Basic Writing of Existentialism. (Ed.) Gordon Marino. New York: Modern Library.

Goutam Karmakar is currently working as a PhD Research Scholar in the Department of Humanities and Social Sciences, National Institute of Technology Durgapur (NITD), India.

Dr. Shri Krishan Rai is an Assistant Professor of English at the Department of Humanities and Social Sciences, National Institute of Technology Durgapur (NITD), India. 